\title{
Variation in structure and composition of two pine forests in Kailash Sacred Landscape, Nepal
}

\author{
C. K. Subedi ${ }^{1 *}$, J. Gurung ${ }^{2}$, S. K. Ghimire ${ }^{3}$, N. Chettri ${ }^{2}$, B. Pasakhala ${ }^{2}$, \\ P. Bhandari ${ }^{1}$ and R. P. Chaudhary ${ }^{1}$
}

Chir pine (Pinus roxburghii Sarg.) and blue pine (Pinus wallichiana A.B. Jacks.) are two common species found in mid-hill forests of Nepal where households largely depend on forest resources for their livelihoods and subsistence. The management of such forests is supported by our understanding of the dynamics in forest structure and species composition and the relationship between different forest community characteristics. This study was designed to determine the variation in species composition and the relationship between various forest community characteristics in two pine forests of Kailash Sacred Landscape, Nepal.Quadrat sampling was applied to collect information on forest species, forest community structure, and disturbance factors.Data was statistically analyzed using IBM SPSS. There were a total of 31 plant species under 28 genera and 20 families in the $P$. roxburghii forest, and 38 plant species under 37 genera and 19 families in the $P$. wallichiana forest. Mean $\mathrm{DBH}$, height and canopy diameter of $P$. roxburghii was $23.98 \mathrm{~cm}, 12.77 \mathrm{~m}$ and $1.97 \mathrm{~m}$, respectively, and that of $P$. wallichiana was $31.5 \mathrm{~cm}, 11.48 \mathrm{~m}$ and $2.79 \mathrm{~m}$, respectively. The relationship between $\mathrm{DBH}$ and both height and crown diameter showed strong relationships in the two forest types.In both forests, DBH and height class distribution showed a hump-shaped (unimodal type) distribution with a greater proportion of medium-sized individuals that indicated disruptive forest regeneration. Fire and treecut were significant disturbance factors in $P$. roxburghii forest, while grazing and trampling were significant in $P$. wallichiana forest. The extent of these disturbance factors as determinants of regeneration and species recruitment is important to assess for effective forest management.

Key words: Community characteristics, disturbance, forest structure, Pinus roxburghii, Pinus wallichiana

$\mathrm{T}^{\mathrm{s}}$ he structure of a forest is determined by biotic and abiotic components (Behera et al., 2012; Mishra et al., 2013), along with human disturbance (Sanderson et al., 2002; Kareiva et al., 2007). Disturbance and biological processesare significant factors determining forest stand development (Franklin et al., 2002). Both forest structure and composition respond to environmental fluctuations and anthropogenic activities (Gairola et al., 2008). Moreover, stand structure, tree size and composition are key characteristics for maintaining ecological integrity and dynamics of forest ecosystems and their functions (Elourad et al., 1997;Kuuluvainen,
2002; Larsen et al., 2005; Merlin et al., 2014). These are also the basis for developing forest management and conservation strategies (Gutierrez and Huth, 2012). In mountain areas, forest structure and composition is regulated by slope orientation and elevation which both affect incoming solar radiation in an area (GallardoCruz et al., 2009). Topographic variables, such as radiation, in turn affect species composition between slopes due to their influence on smallscale abiotic environmental variables (FerrerCastan and Vetaas, 2003; Paudel and Vetaas, 2014).

\footnotetext{
1. Research Centre for Applied Science and Technology (RECAST), Tribhuvan University, Kirtipur, Kathmandu, Nepal * E-mail: chandraks2000@yahoo.com

2. International Centre for Integrated Mountain Development (ICIMOD), Khumaltar, Lalitpur, Nepal

3. Central Department of Botany, Tribhuvan University, Kirtipur, Kathmandu, Nepal
} 
Chir pine (Pinus roxburghii Sarg.) and blue pine (Pinus wallichiana A.B. Jacks.) are two pine species distributed mainly in the western Himalaya while also flourishing in Bhutan (Ohsawa et al., 1986). They are commercially important plant species in the Himalaya used for timber, turpentine and several medicinal and cultural purposes (Tiwari, 1994; Siddique et al., 2009). Several research studies have been conducted on these pine species from different parts of the Himalaya. A review of $P$. roxburghii was made by Kaushik et al. (2013) on ethnobotany and phytopharmacology. Dendrochronological study was carried out to determine the impact of climate change on growth of $P$. wallichiana (Bajwa et al., 2015). Similar work was conducted on $P$. roxburghii to understand stand age, structure, soil erosion, disturbance history and tree health (Speer et al., 2016). Composition, population structure and diversity of $P$. wallichiana in Garhwal Himalaya with special reference to altitude and aspect was studied by Bhandari (2003). Study on phytosociology of $P$. roxburghii was conducted by Siddique et al. (2009) in the lesser Himalaya and Hindukush range of Pakistan. Ghimire et al. (2010) carried out research on regeneration of $P$. wallichiana in the trans-Himalayan dry valley of north-central Nepal. Most research conducted in Nepal on these pine species are focused on allometric relationships for biomass prediction (Sharma and Pukkala, 1990), basal area growth model (Gyawali et al., 2015), dendrochronology (Schwab et al., 2015) and carbon sequestration (Aryal, 2016).

In Nepal, chir pine and blue pine constitute $8.45 \%$ and $3.37 \%$, respectively, of total forest area (DFRS, 2015). The two species are also the major constituents of forests in the midhills of Nepal (DFRS, 2015) where households largely depend on forest resources for their livelihoods and subsistence (Springate-Baginski et al., 2003). Long-term studies on forest socio-ecological systems are lacking in Nepal. This study was conducted in two pine-dominated community managed forests of Kailash Sacred Landscape (KSL) in Nepal to collect baseline information as part of a long-term socio-ecological study of forest ecosystems in the landscape. Knowledge on forest structure and composition is important for their management, but such studies are lacking in the landscape. Thus, the findings of this study will contribute to forest management while also providingbaseline data for long-term forest monitoring. The study addresses the following questions: 1) what are the variations in forest structure and species composition in chir pine and blue pine forests? and 2) what is the relationship between different community characteristics in the two pine forests?

\section{Materials and method}

\section{Study area}

The study was carried out in KSL-Nepal (MFSC, 2016) (Fig. 1). The landscape, whichextendsbetween $29^{\circ} 22^{\prime} \mathrm{N}$ to $30^{\circ} 45^{\prime} \mathrm{N}$ latitude and $80^{\circ} 15^{\prime} \mathrm{E}$ to $82^{\circ} 10^{\prime} \mathrm{E}$ longitude, covers an area of 13,289 sq. km and comprises the districts of Baitadi, Bajhang, Darchula and Humla.Altitudesin KSL-Nepal range from 390 m to $7,132 \mathrm{~m}$ above sea level (masl). The climatic condition of the area is characterized by high rainfall and humidity, with average rainfall of 2,129 $\mathrm{mm}$. Average maximum and minimum temperature is $18.6^{\circ} \mathrm{C}$ and $7.7^{\circ} \mathrm{C}$, respectively. Forests occupy almost $30 \%$ of the total area of KSL-Nepal of which subtropical broadleaved forests (with Shorea robusta, Terminalia alata, and Pinus roxburghii) constitute $10 \%$ and uppermontane conifer forests (with Cedrus deodara, Cupressus torulosa, Tsuga dumosa, and Pinus wallichiana) constitute 3\%.

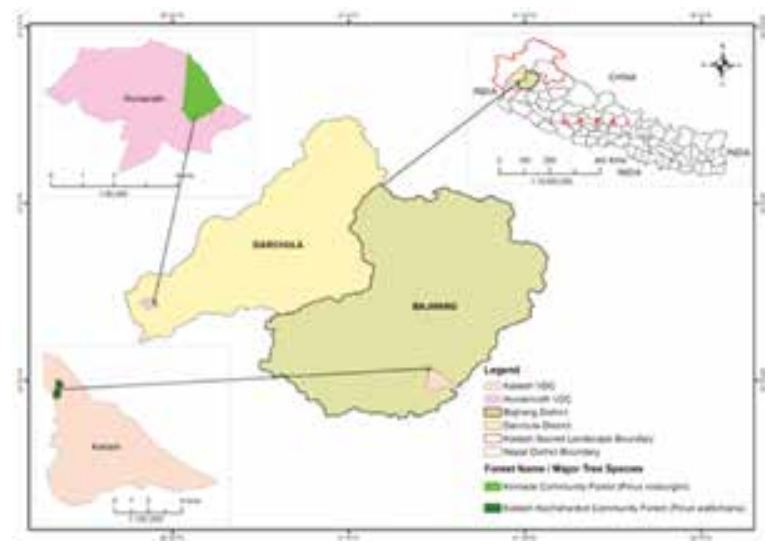

Fig. 1: Map of the study area.

The forest survey was conducted in two community managed forests in the landscape: Kirmadhe Sinnadi in Hunainath Village Development Committee (VDC) of Darchula district and Kailash Kachaharikot Mahila in Kailash VDC of Bajhang district. Kirmadhe 
Sinnadi community forest (CF) covers an area of 50.76 hectares (ha). Altitudes in this CF range from 1808 to $1958 \mathrm{~m}$ asl and slopes between $5^{\circ}$ to $21^{\circ}$ with the forest oriented towards east and west. $P$. roxburghii is the dominant tree species while other tree species include Quercus lanata, Rhododendron arboreum and Myrica esculenta. Kailash Kachaharikot Mahila CF covers an area of 20 hectares. Altitudes range from 1800 to 2100 masl and slope between $20^{\circ}$ to $35^{\circ}$ with the forest oriented towards south and west. P. wallichiana is the dominant tree species in this CF.

\section{Field methods}

Field work was conducted between May and June 2016 to establish permanent forest monitoring plots in the two pine forests. The boundaries of both forests were delineated using a Global Positioning System (GPS) device - Garmin Oregon 650. The forest boundary was then transferred to Google Earth map where a $20 \mathrm{~m} * 25 \mathrm{~m}$ grid was overlaid. Sample forest plots were then randomly selected and verified in the field. Based on the total size of the CFs, ten permanent plots were established in $P$. roxburghii forest and four in $P$. wallichiana forest. Each plot was further divided into 20 $5 \mathrm{~m} * 5 \mathrm{~m}$ subplots to collect data on plant life forms (Fig. 2). The location of each plot was recorded using a GPS device, and topographic variables including altitude, slope and aspect were recorded with an altimeter (Suunto). In each plot, grazing, trampling, cutting, lopping and fire were visually estimated as disturbance variables. They were recorded on a scale ranging from 0 (no visible sign of disturbance) to 3 (high disturbance). Ocular estimate of top canopy (tree crown), mid canopy (canopy of shrubs and saplings) and low canopy (canopy of herbs, forbs and seedlings) was made from the center of each subplot.

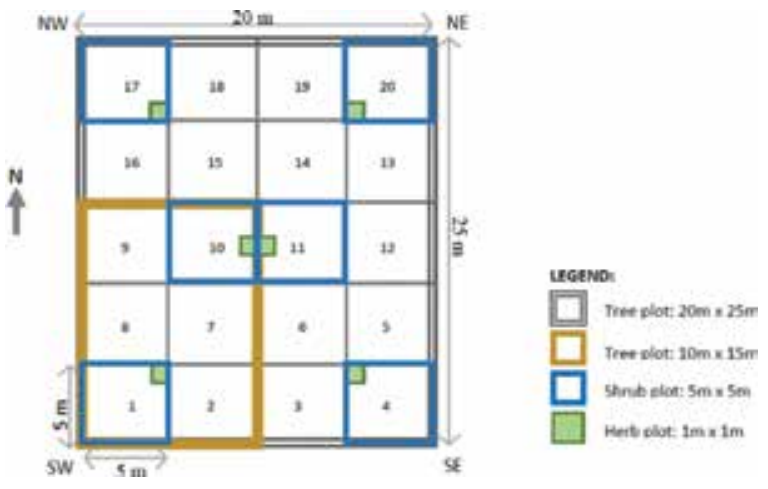

\section{Vegetation sampling}

Based on diameter at breast height (DBH) and height $(\mathrm{H})$ of the individual, plant species were classified in to three categories, viz. tree $(>10$ $\mathrm{DBH})$, saplings $(<10 \mathrm{~cm} \mathrm{DBH}$ and $\mathrm{H}>1.3 \mathrm{~m})$ and seedlings $(\mathrm{H}<1.3 \mathrm{~m})$ (Newton, 2007). Individual trees were recorded in the entire $20 \mathrm{~m}^{\star} 25 \mathrm{~m}$ plot (hereby referred here as 'tree plot'). DBH of each individual tree was measured at $1.3 \mathrm{~m}$ height from the ground usingMillion diameter tape(YAMAYO) and its height with a Vertex IV (Haglof Sweden). Canopy of each individual tree was measured in eight directions from the center. Tree saplings were measured in a nested $10 \mathrm{~m}^{\star} 15$ msubplot (sapling plot) within the tree plot. The number and percentage cover of shrubs were recorded in six $5 \mathrm{~m}^{\star} 5 \mathrm{~m}$ subplots(shrub plot), four of which were fixed at the corners of the tree plot and two at the center. Similarly six $1 \mathrm{~m}^{\star} 1 \mathrm{~m}$ subplots(herb plot) nested within the subplot were used to record herbaceous vegetation. The number of herb species and an ocular estimate of their percent cover was recorded. Most of the plant species were identified in the field withstandard flora (Stainton, 1997; Polunin and Stainton, 2000). Unidentified plant species were collected and later identified usingavailable literature (Sharma and Kachroo, 1983; Stainton, 1997; Polunin and Stainton, 2000) and by consulting herbarium specimens housed at Tribhuvan University Central Herbarium (TUCH) and National Herbarium and Plant Laboratory (KATH). Plant species nomenclature follows Press et al. (2000).

\section{Statistical analysis}

Spearmen's correlation was used to determine relationships between different characteristics of forest community and environmental variables. Linear regression analysis was performed to determine relationships between different forest community characteristics. The regression coefficients and equationswere obtained through a fitted line on the scattered plot, and $F$ and $p$ valueswere obtained through ANOVA. Before regression analysis,all disturbance variables (grazing, trampling, cut, harvesting and fire) were combined through dimension reduction process in Principle Component Analysis (PCA) to obtain a combined measure of disturbance. IBM SPSS was used for data analysis.

Fig: 2 Vegetation sampling design 
Table 1: Floristic composition in pine forests

\begin{tabular}{|c|l|l|l|}
\hline \multirow{2}{*}{$\begin{array}{c}\text { Life } \\
\text { form }\end{array}$} & \multicolumn{2}{|c|}{ Occurring in only } & \multicolumn{1}{|c|}{ Common to both forests } \\
\cline { 2 - 4 } Trees & $\begin{array}{l}\text { Plnus nepalensis, } \\
\text { Quercus lanata }\end{array}$ & $\begin{array}{l}\text { Symplocos paniculata, Viburnum } \\
\text { erubescens }\end{array}$ & $\begin{array}{l}\text { Lyonia ovalifolia, } \\
\text { Rhododendron arboreum }\end{array}$ \\
\hline Shrubs & $\begin{array}{l}\text { Hedysarum } \\
\text { kumaonense, Rubus } \\
\text { paniculatus }\end{array}$ & $\begin{array}{l}\text { Cotoneaster frigidus, } \\
\text { Cotoneaster microphyllus, } \\
\text { Daphne papyracea, Indigofera } \\
\text { heterantha, Inulacappa, Myrsine } \\
\text { africana, Prinsepia utilis, } \\
\text { Pyracantha crenulata, Smilax } \\
\text { aspera, Spiraea bella and } \\
\text { Viburnum cotinifolium }\end{array}$ & $\begin{array}{l}\text { Berberis asiatica, Rubus } \\
\text { ellipticus }\end{array}$ \\
\hline Herbs & $\begin{array}{l}\text { Anaphalis busua, } \\
\text { Cirsium wallichii, } \\
\text { Commelina } \\
\text { benghalensis, } \\
\text { Curculigo orchioides, } \\
\text { Drosera peltata, } \\
\text { Fimbristylis } \\
\text { dichotoma, } \\
\text { Hypericum } \\
\text { japonicum, } \\
\text { Reinwardtia indica }\end{array}$ & $\begin{array}{l}\text { Gaultheria nummularioides, } \\
\text { Gnaphalium affine, Origanum } \\
\text { vulgare, Potentilla sundaica }\end{array}$ & $\begin{array}{l}\text { Anaphalis triplinervis, } \\
\text { Carex filicina, Erigeron } \\
\text { karvinskianus, Flemingia } \\
\text { strobilifera, Fragaria indica, } \\
\text { Galiu melegans, Gonostegia } \\
\text { hirta, Imperata cylindrica, } \\
\text { Micromeria biflora, Oplismenus } \\
\text { compositus, Oxalis corniculata, } \\
\text { Taraxacum parvulum, Viola } \\
\text { serpens, Ageratina adenophora }\end{array}$ \\
\hline
\end{tabular}

\section{Results and discussion}

\section{Floristic composition}

There were 31 plant species belonging to 28 genera and 20 families in $P$. roxburghii forest, and 38 plant species belonging to 37 genera and 19 families in $P$. wallichiana forest. Based on life forms, 22 herbs, 4 shrubs and 5 trees were recorded in the $P$. roxburghii forest, and 19 herbs, 13 shrubs and 4 tree species were found in P. wallichiana forest. 14 herbs, 2 shrubs, and 2 trees were common to both forests while 8 herbs, 2 shrubs and 3 trees were found exclusively in P. roxburghii forest and 6 herbs, 11 shrubs and 3 trees exclusively in P. wallichiana forest (Table $1)$.

P. roxburghii is invasive in nature and can easily replace broadleaved species, ultimately leading to monoculture forest development (Bhandari, 2003). It has competitive superiority than other species in obtaining resources (Bargali, 1997). It is a light demanding and fire promoting species. Surface fire causes substantial loss of nitrogen, and this depletion on nitrogen is the major cause of monoculture development of pineforests
(Singh et al., 1984). Phytosociological analysis showed that $P$. roxburghii was generally distributed in pure form (Siddiqui et al. 2009). Pine forests are affected by fires especially in the summer season resulting in deterioration of soil fertility and development of new species. Fire reduces total organic matter, phosphorus and potassium (Benerjee and Chand, 1981; Ghotz and Fischer, 1982). In comparison to $P$. roxburghii, $P$. wallichiana tends to share its habitat with other tree species (Bhandari, 2003) resulting in higher species richness in this study.

\section{Forest structure}

The DBH and height class distribution of $P$. roxburghii population is presented in Fig. 3 and of $P$. wallichianain Fig. 4. In both forests, DBH and height class distribution showed humpshaped (unimodal type) distribution with greater proportion of medium-sized individuals. There was a gradual increase in the proportion of individuals of DBH class up to $>20-<30 \mathrm{~cm}$ for $P$. roxburghii and $>30-<40$ for $P$. wallichiana, and height class upto $>10-<15$ mfor $P$. roxburghii and $>15-<20 \mathrm{~m}$ for $P$. wallichiana after which height class gradually decreased. 


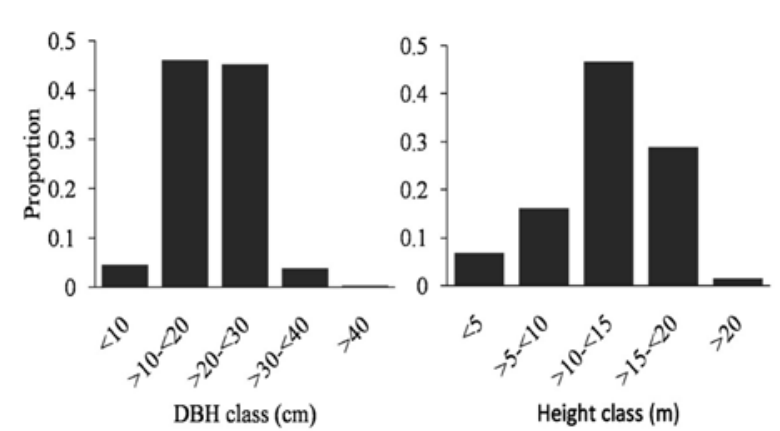

Fig. 3 DBH and height class distribution of $P$. roxburghii

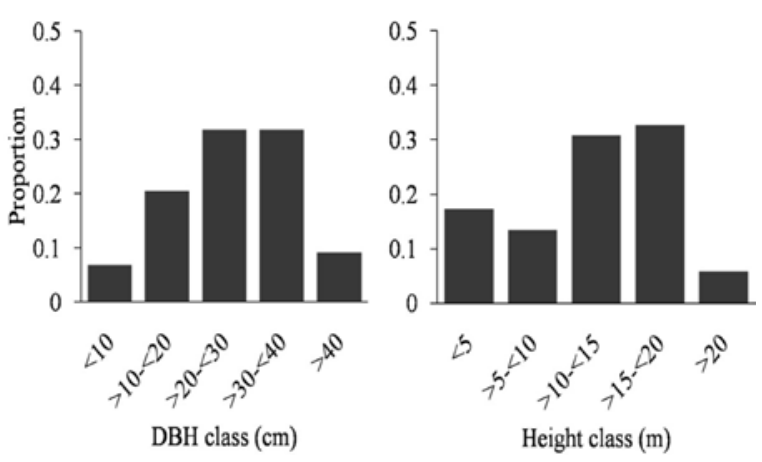

Fig. $4 \mathrm{DBH}$ and height class distribution of $P$. wallichiana

The size distribution of trees is an important indicator for population dynamics and for forest management (Kohira and Ninomiya, 2003; White et al., 2007). This study showed that there were fewer juveniles as compared to adults in the two forests indicating disruptive regeneration probably due to disturbance (Condit et al., 1998; George et al., 2005; Deb and Sundriyal, 2008). A study on $P$. roxburghii in Bhutan showed unimodal distribution resulting from anthropogenic and natural disturbances (Wangda and Ohsawa, 2006). Both forests in KSL-Nepal are used by local communities, especially for extraction of timber, and hence the preference for large-sized trees. While felling such trees, the resulting disturbance on seedlings and saplings could possibly affect their regeneration.

\section{Relationship between forest community characteristics}

The forest community characteristics of $P$. roxburghii and $P$. wallichiana are presented in Table 2. Density of pine was high in both forests. Mean DBH, height and canopy diameter of $P$. roxburghii was $23.98 \mathrm{~cm}, 12.77 \mathrm{~m}$ and 1.97 $\mathrm{m}$, respectively, and that of $P$. wallichiana was $31.5 \mathrm{~cm}, 11.48 \mathrm{~m}$ and $2.79 \mathrm{~m}$, respectively. The mean top and mid canopy cover was higher in $P$. wallichiana forest than in $P$. roxburghii forest, but low canopy cover was highest in the latter forest.

Table 2: Community characteristics of $P$. roxburghii and $P$. wallichiana forest

\begin{tabular}{|c|c|c|c|}
\hline \multirow{2}{*}{\multicolumn{2}{|c|}{$\begin{array}{l}\text { Variables } \\
\text { Mean (SE) }\end{array}$}} & $\begin{array}{c}P . \\
\text { roxburghii }\end{array}$ & $\begin{array}{c}P . \\
\text { wallichiana }\end{array}$ \\
\hline & & Mean (SE) & \\
\hline \multicolumn{2}{|c|}{$\begin{array}{l}\text { Number of tree } \\
\text { species }\end{array}$} & $1.60(0.31)$ & $2.00(0.45)$ \\
\hline \multicolumn{2}{|c|}{$\begin{array}{l}\text { Density of Pine } \\
\text { (number/ha) }\end{array}$} & $168.5(7.15)$ & $65.00(3.73)$ \\
\hline \multicolumn{2}{|c|}{ Mean DBH $(\mathrm{cm})$} & $23.99(1.78)$ & $31.02(4.70)$ \\
\hline \multicolumn{2}{|c|}{ Mean height $(\mathrm{m})$} & $12.77(0.83)$ & $11.49(1.02)$ \\
\hline \multicolumn{2}{|c|}{$\begin{array}{l}\text { Mean canopy } \\
\text { diameter }(\mathrm{m})\end{array}$} & $1.97(0.19)$ & $2.80(0.15)$ \\
\hline \multirow{3}{*}{$\begin{array}{l}\text { Canopy } \\
(\%)\end{array}$} & Top & $27.03(3.36)$ & $32.75(3.31)$ \\
\hline & Mid & $4.25(0.60)$ & $16.50(1.96)$ \\
\hline & Low & $14.59(1.18)$ & $12.00(2.61)$ \\
\hline
\end{tabular}

The dimension reduction process in PCA resulted in two PCA factors explaining $56.5 \%$ of variance: PCA factor 1 (31.32\% variance) explained grazing (0.841) and trampling (0.858) as main associated variables; and PCA factor 2 (25.23\% variance) explained tree cut $(0.807)$ and fire $(0.734)$ as main associated variables in $P$. roxburghii forest. In $P$. wallichiana forest, two PCA factors were obtained explaining $55.2 \%$ of variance: PCA factor 1 (35.25\% variance) explained grazing $(0.801)$ and trampling $(0.851)$ as main associated variables, and PCA factor 2 (19.95\% variance) explained tree cut (0.782), harvesting $(0.517)$ and fire $(0.539)$ as main associated variables.

The density of $P$. roxburghii was negatively correlated with mean DBH $(\mathrm{r}=-0.872, \mathrm{p}=0.01)$ and canopy diameter $(\mathrm{r}=-0.770, \mathrm{p}=0.01)$ and positively with disturbance factor 2 , i.e fire and cut $(r=0.792, p=0.01)$. Since the local villagers had extracted large sized trees for timber and fire allows regeneration of pine seedlings (Paucas et al., 2004), large sized tree with larger DBH were absent in the forest. P. roxburghii can tolerate more stress and potentially colonize disturbed and moisture-deficient areas (Singh and Singh, 
1992; Ryan and Yoder, 1997). Fire helped liberate seeds from cones allowing their regeneration and monospecific stand development in Pinus halepensis (Pausas et al., 2004; Moya et al., 2007). Tang et al. (2013) reported that the natural recovery of Pinus yunnanensis was more efficient after fire contributing to the density of pine in central Yunan, China. The mean DBH was positively correlated with mean canopy diameter $(\mathrm{r}=0.841, \mathrm{p}=0.01)$. The mean crown radius was the function of stem size, stand density and site productivity and the canopy radius increased linearly with DBH (Avsar and Ayyildiz, 2005; Attocchi and Skovsgaard, 2015).

Strong negative correlation was found with canopy diameter and number of tree species $(\mathrm{r}=0.987, \mathrm{p}=$ 0.05 ) in $P$. wallichiana forest. Crown morphology has important implications to compete with other species in a community (Messier, 1996; Messier et al., 1999). High tree canopy cover reduces the amount of solar radiation to the ground while facilitating more litter deposition which is not a favorable condition for seedling establishment (Spanos et al., 2001).

\section{DBH-height relationship}

A significant linear relationship $(\mathrm{p}<0.001)$ was found between $\mathrm{DBH}$ and height $\left(\mathrm{R}^{2}=0.571\right.$ for $P$. roxburghii and 0.551 for $P$. wallichiana) (Fig. 5 (a) and (b)). The strength in relationship between DBH and height of the two pine forests was not significantly different. The height-diameter relationship of trees are stand specific, site specific, and time specific and also differ within a site due to competition among trees (Trincado et al., 2007; Pretzsch, 2009; Schmidt et al., 2011). Tree diameter has a significant correlation with the height and age of the forest stand and thereby directly affects sustainable volume production (Khan et al., 2016). This correlation depends on the growing environment and stand conditions (Calama and Montero, 2004; Sharma and Zhang, 2004).

\section{DBH-crown diameter relationship}

Measurement of crown diameter is usually not carried out in forest inventory but is important to measure some competitive measures and to determine canopy cover (Biging et al., 1995; Gill et al., 2000; Popescu et al., 2003). The $\mathrm{R}^{2}$ value obtained from regression between DBH and crown diameter in this study was 0.572 in $P$. roxburghii forest and 0.422 in $P$. wallichiana forest (Fig. 5 and 6). Gill et al. (2000) developed models for different coniferous trees of California and obtained $\mathrm{R}^{2}$ values between 0.2691 and 0.6077 where DBH predicted most of the model. Incorporation of crown area into models improved accuracy of the predictions (Nakai et al., 2010; Gonzalez-Benecke et al., 2014).

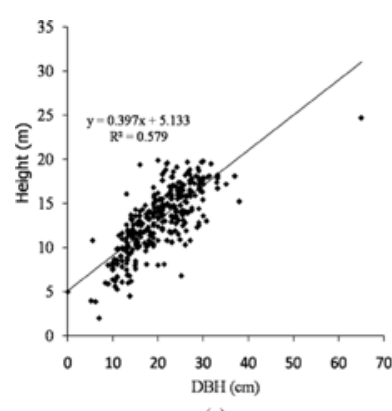

(a)

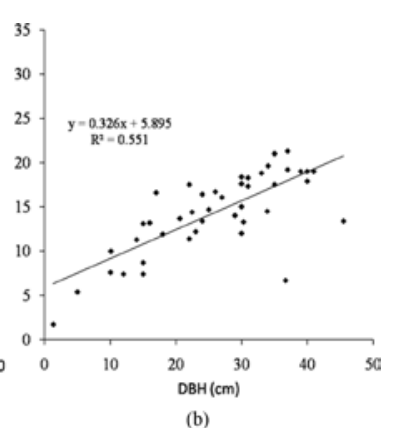

(b)
Fig 5 Regression between DBH and height of (a) P. roxburghii (b)P. wallichiana

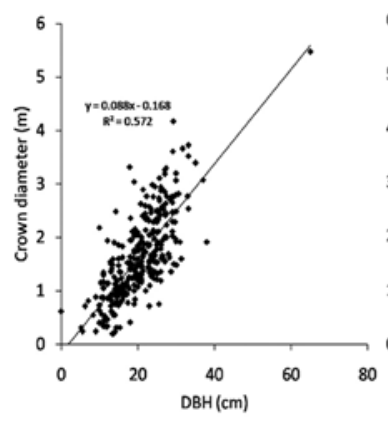

(a)

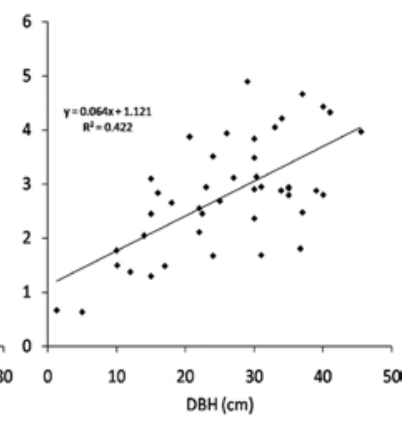

(b)
Fig 6 Regression between height and crown diameter of (a) P. roxburghii and (b) P. wallichiana

\section{Conclusion}

Pinus roxburghii and Pinus wallichiana are important needleleaved species occurring in subtropical broadleaved and upper montane conifer forests in KSL-Nepal. This study presents the forest structure and species composition of two pine forests selected for conducting long term socio-ecological research in the landscape. Both forests were dominated by the respective tree species, with mean number of tree species being $1.60( \pm 0.31)$ in $P$. roxburghii forests and 2.00 $( \pm 0.45)$ in $P$. wallichiana forests. Tree density 
averaged $168.5( \pm 7.15)$ and $65.0( \pm 3.73)$ stems per ha. in $P$. roxburghii and $P$. wallichiana forests, respectively. Size distribution of trees displayed a unimodal type with greater proportion of medium-sized individuals. The structure of both forests indicates that they are heavily disturbed. Fire and tree cut were significant disturbance factors in $P$. roxburghii forest, while grazing and trampling were significant in P. wallichiana forest. The extent of these disturbance factors as determinants of regeneration and species recruitment is important to assess for effective forest management.

\section{Acknowledgement}

This study was supported by Kailash Sacred Landscape Conservation and Development Initiative (KSLCDI) Nepal, a collaborative programme between Ministry of Forests and Environment, Government of Nepal; Research Centre for Applied Science and Technology, Tribhuvan University; and International Centre for Integrated Mountain Development; and supported by the German Federal Ministry for Economic Cooperation and Development (BMZ) through the Deutsche Gesellschaft für Internationale Zusammenarbeit (GIZ) $\mathrm{GmbH}$ and the United Kingdom's Department for International Development (DFID) - UK Aid, as well as by the core funds of ICIMOD contributed by the governments of Afghanistan, Australia, Austria, Bangladesh, Bhutan, China, India, Myanmar, Nepal, Norway, Pakistan, Switzerland, and the United Kingdom. The views and interpretation in this publication are those of the authors and should not be ascribed to MoFE, RECAST, ICIMOD or their donors.

We are thankful to Santosh Thapa, Mohan Pandey, Neha Bisht, and community forest user groups for their help during data collection, and to Sunil Thapa for preparing the study area map. The District Forest Offices of Bajhang and Darchula are acknowledged for their support.

\section{References}

Aryal, B. 2016. Carbon sequestration in a fired ecosystem of Pinus roxburghii forest in Rasuwa District, Nepal. Society of Natural Resources Conservation and Development (SoNaReCoDe), Kathmandu in collaboration with NAST/ADB, MCCRMD (TA 7984 NEP).

Attocchi, G. and Skovsgaard, J.P. 2015. Crown radius of pedunculate oak (Quercus robur L.) depending on stem size, stand density and site productivity. Scandinavian Journal of Forest Research 30 (4): 289-303http:// dx.doi.org/10.1080/02827581.2014.100178 2.

Avsar, M. D. and Ayyildiz, V. 2005. The relationships between diameter at breast height, tree height and crown diameter in Lebanon cedars (Cedrus libani A. Rich.) of the Yavsan Mountain, Kahramanmaras, Turkey. Pakistan Journal of Biological Science 8 (9): 1228-1232.

Bajwa, G.A., Shahzad, M.K. and Satti, H.K. 2015. Climate change and its impacts on growth of Blue pine (Pinus wallichiana) in Murree Forest Division, Pakistan. Science, Technology and Development 34 (1): $27-$ 34. DOI: 10.3923/std.2015.27.34.

Bargali, K. 1997. Role of light, moisture and nutrient availability in replacement of Quercus leucotrichophora by Pinus roxburghii in central Himalaya. Journal of Tropical Forest Science 10 (2): 262-270.

Behera, S.K., Mishra, A.K., Sahu, N., Kumar, A., Singh, N., Kumar, A., Bajpai, A., Chaudhary, L.B., Khare, P.B. and Tuli, R. 2012. The study of microclimate in response to different plant community associations in tropical moist deciduous forest from northern India. Biodiversity and Conservation 21: 1159-1176. doi:10.1007/s10531-0120230-5.

Benerjee, S.P. and Chand, S. 1981. Physicochemical properties and moisture characteristics of soil as influenced by forest fire. Indian Forester 107: 178-182.

Bhandari, B. S. 2003. Blue pine (Pinus wallichiana) forest stands of Garhwal Himalaya: composition, population structure and diversity.Journal of Tropical Forest Science 15 (1): $26-36$. 
Biging, G.S. and Dobbertin, M. 1995. Evaluation of competition indices in individual tree growth models.Forest Science 41 (2): $360-377$.

Calama, R. and Montero, G. 2004. Interregional nonlinear height-diameter model with random coefficients for stone pine in Spain. Canadian Journal of Forest Research 34:150-163.

Condit, R., Sukumar, R., Hubbell, P. and Foster, R.B. 1998. Predicting population trends from size distributions: A direct test in a tropical tree community. The American Naturalist 152 (4): 495-509.

Deb, P. and Sundriyal, R.C. 2008. Tree regeneration and seedling survival patterns in old-growth lowland tropical rainforest in Namdapha National Park, north-east India. Forest Ecology and Management 255: 3995-4006.

DFRS. 2015. State of Nepal's Forests. Forest Resource Assessment (FRA) Nepal, Department of Forest Research and Survey (DFRS), Kathmandu, Nepal.

Elouard, C., Houllier, F., Pascal, J.P., Pelissier, R. and Ramesh, B.R. 1997. Dynamics of the Dense Moist Evergreen Forests: Long term monitoring of an experimental station in Kodagu. Karnataka, India: Institut Français de Pondichéry. https://hal.archivesouvertes.fr/hal-00373536.

Ferrer-Castan, D. and Vetaas, O.R. 2003. Floristic variation, chronological types and diversity: Do they correspond at broad and local scales? Diversity and Distribution 9: 221-235. doi: 10.1046/j.14724642.2003.00009.x.

Franklin, J. F., Spies, T. A., Pelt, R. V., Carey, A.B., Thonburgh, D.A., Berg, D.R., Lindenmayer, D. B., Harmon, M.E., Keeton, W. S., Shaw, D. C., Bible, K. and Chen, J. 2002. Disturbances and structural development of natural forest ecosystems with silvicultural implications, using Douglas-fir forests as an example. Forest Ecology and Management 155: 399— 423.
Gairola, S., Rawal, R.S and Todaria, N.P. 2008. Forest vegetation patterns along an altitudinal gradient in sub-alpine zone of west Himalaya, India. African Journal of Plant Science 2 (6): 042—048.

Gallardo Cruz, A. J., Pérez-García, E. A. and Meave, J.A. 2009. $\beta$-diversity and vegetation structure as influenced by slope, aspect and altitude in a seasonally dry tropical landscape. Landscape Ecology 24: 473 - 482. doi: 10.1007/s10980-0099332-1.

George, A. K., Walker, K. F. and Lewis, M. M. 2005. Population status of eucalypt trees on the river Murray floodplain, South Australia. River Research and Application 21: $271-282$.

Ghimire, B., Mainali, K. P., Lekhak, H. D., Chaudhary, R. P and Ghimeray, A. K. 2010. Regeneration of Pinus wallichiana $\mathrm{AB}$ Jackson in a trans-Himalayan dry valley of north-central Nepal. Himalayan Journal of Sciences 6 (8): 19-26.

Ghotz, H. L. and Fisher, R. F. 1982. Organic matter production and distribution in slash pine (Pinus elliottii) plantation. Ecology 63: 1827-1839.

Gill, S. J., Biging, G. S. and Murphy, E. C. 2000. Modeling conifer tree crown radius and estimating canopy cover. Forest Ecology and Management 126: 405-416.

Gutiérrez, A. G. and Huth, A. 2012. Successional stages of primary temperate rainforests of Chiloé Island, Chile. Perspectives in Plant Ecology, Evolution and Systematics 14: $243-256$.

Gyawali, A., Sharma, R. P. and Bhandari, S. K. 2015. Individual tree basal area growth models for Chir pine (Pinus roxberghii Sarg.) in western Nepal. Journal of Forest Science 61 (12): 535—543 doi: 10.17221/51/2015-JFS.

Kareiva, P., Watts, S., McDonald, R. and Boucher, T. 2007. Domesticated nature: shaping landscapes and ecosystems for human welfare. Science 316 (5833): 1866-1869. 
Kaushik, P., Kaushik, D. and Khokra, S. L. 2013. Ethnobotany and phytopharmacology of Pinus roxburghii Sargent: a plant review. Journal of Integrative Medicine 11 (6): $371-376$.

Khan, M.S., Khan, S., Shah, W., Hussain, A., and Shah, M. 2016. Height growth, diameter increment and age relationship response to sustainable volume of subtropical Chir pine (Pinus roxburghii) forest of Karaker Barikot forest. Pure and Applied Biology 5 (4): $760-767$.

Kohira, M. and Ninomiya, I. 2003. Detecting tree populations at risk for forest conservation management: using single-year vs. longterm inventory data. Forest Ecology and Management 174: 423-435.

Kuuluvainen, T. 2002. Natural variability of forests as a reference for restoring and managing biological diversity in boreal Fennoscandia. Silva Fenn. 36: 97-125.

Larsen, T. H., Williams, N. M. and Kremen, C. 2005. Extinction order and altered community structure rapidly disrupt ecosystem functioning. Ecology Letters 8 (5): 538-547. doi: 10.1111/j. 14610248.2005.00749.x

Merlin, M., Perot, T., Perret S., Korboulewsky, N. and Vallet, P. 2014. Effects of stand composition and tree size on resistance and resilience to drought in sessile oak and Scots pine. Forest Ecology and Management 339 (2015): 22-33. http:// dx.doi.org/10.1016/j.foreco.2014.11.032

Messier, C. 1996. Managing light and understory vegetation in boreal and temperate broadleaf-conifer forests. In Silviculture of Temperate and Boreal Broadleaf-Conifer Mixtures.Comeau, P. G. and Thomas, K. D. (Eds)Ministry of Forests Research Program, Victoria.

Messier, C., Doucet, R., Ruel, J. C., Lechowicz, M. J., Kelly, C. and Claveau, Y. 1999. Functional ecology of advance regeneration in relation to light in boreal forests. CanadianJournalof ForestResearch 29: 812-823.
MFSC. 2016.Conservation Landscapes of Nepal. Ministry of Forests and Soil Conservation, Government of Nepal.

Mishra, A. K., Behera, S. K., Singh, K., Chaudhary, L. B., Mishra, R.M. and Singh, B. 2013. Effect of abiotic factors on community structure of understory vegetation in moist deciduous forests of north India. Forest Science and Practice. 15 (4): 261-273. doi: 10.1007/s11632-013-0415-3.

Moya, D., Espelta, J. M., Verkaik, I., LópezSerrano, F. and de Las Heras, J. 2007. Tree density and site quality influence on Pinus halepensis Mill. reproductive characteristics after large fires. Annals of Forest Science 64: $649-656$.

Nakai Y., Hosoi, F. and Omasa, K. 2010. Estimation of coniferous standing tree volume using airborne LiDAR and passive optical remote sensing. Journal of Agricultural Meteorology 66: $111-116$.

Newton, A. C. 2007. Forest Ecology and Conservation. Oxford University Press, Oxford, New York.

Ohsawa, M., Shakya, P. R. and Numata, M. 1986. Distribution and succession of west Himalayan foresttypes in the western part of the Nepal Himalaya. Mountain Research and Development 6 (2): 143-157.

Paudel, S. and Vetaas, O. R. 2014. Effects of topography and land use on woody plant species composition and beta diversity in an arid trans-Himalayan landscape, Nepal. Journal of Mountain Science 11 (5): 1112-1122. doi: 10.1007/s11629-0132858-3.

Pausas, J. G., Ribeiro, E. and Vallejo, R. V. 2004. Post-fire regeneration variability of Pinus halepensis in the eastern Iberian Peninsula. Forest Ecology and Management 203: 251-259.

Polunin, A. and Stainton, A. 2000. Flowers of the Himalaya. Oxford University Press, New Delhi, India. 
Popescu, S.C., Wynne, R.H. and Nelson, R.F. 2003. Measuring individual tree crown diameter with LiDARand assessing its influence on estimating forest volume and biomass. Canadian Journal of Remote Sensing 29 (5): $564-577$.

Press, J. R., Shrestha, K. K. and Sutton, D. A. 2000. Annotated Checklist of the Flowering Plants of Nepal. The natural History Museum, London.

Pretzsch H. 2009. Forest dynamics, growth and yield: from measurement to model. Berlin, Germany: Springer Verlag, 664 pgs.

Price, M. F., Gratzer, G., Duguma, L. A., Kholer, T., Maselli, D. and Romeo, R. 2011. Mountain Forests in a Changing World Realizing Values, Addressing Challenges. FAO/MPS and SDC, Rome, Italy.

Ryan, M.G. and Yoder, B.J. 1997. Hydraulic limits to tree height and tree growth. Bioscience 47: $235-242$.

Sanderson, E. W., Jaiteh, M., Levy, M.A., Redfrod, K. H., Wannebo, A. V. and Woolmer, G. 2002. The human footprint and the last of the wild. Bioscience 52:891-904.

Schmidt,M., Kiviste, A. andvon Gadow, K.2011. A spatially explicit height-diameter model for Scots pine in Estonia. European Journal of Forest Research 130: 303-315.

Schwab, N., Wilson, R., Helle, G., Gärtner, H. (2015):Proceedings of the Dendro Symposium 2014: May 6-10, Aviemore, Scotland, UK, (Scientific Technical Report;15/06), 13th TRACE conference (Tree Rings in Archaeology, Climatology and Ecology) (Aviemore, Scotland 2014), Potsdam: Deutsches GeoForschungsZentrum GFZ, 122pages.

Sharma, M. S. and Kachroo, P. 1981. Flora of Jammu and Plants of Neighbourhood. Bishen Singh Mahendra Singh Pal Singh. Dehradun, India.

Sharma, E.R. and Pukkala, T. 1990. Volume Equations and Biomass Prediction of
Forest Trees of Nepal. Publication no 47, Forest Survey and Statistics Division, Ministry of Forests and Soil Conservation, Kathmandu, Nepal.

Sharma, M., and Zhang, S.Y. 2004. Heightdiameter models using stand characteristics for Pinus banksiana and Picea mariana. Scandinavian Journal of Forest Research 19: $442-451$.

Siddiqui, M. H., Ahmed M., Wahav, M., Khan, S., Khan, M. U., Nazim, K. and Hussain, S. S. 2009. Phytosociology of Pinus roxburghii Sargent. (Chir pine) in lesser Himalayan and Hindukush range of Pakistan. Pakistan Journal of Botany 41 (5): 2357-2369.

Singh, J.S. and Singh, S.P., 1992. Forests of Himalaya: Structure, Functioning and Impact of Man. Gyanodaya Prakashan, Nainital, India.

Singh, J. S., Rawat, Y. S. and Chaturvedi, A. P. 1984. Replacement of oak forest with pine in the Himalya affects nitrogen cycle. Nature 311: $54-56$.

Spanos I, Radoglou, K. and Raftoyannis, Y. 2001. Site quality effect on post-fire regeneration of Pinus brutia forest on a Greek Island. Applied Vegetation Science 4: 229-236.

Speer, J. H., Brauning, A., Zhang, Q. B., Pourtahmasi, K., Gaire, N. P., Dawadi, B., Rana, P., Dhakal, Y.R., Acharya, R. H., Adhikari, D. L., Adhikari, S., Aryal, P. C., Bagale, D., Baniya, B., Bhandari, S., Dahal, N., Dahal, S., Ganbaatar, N., Giri, A., Gurung, D. B., Khandu, Y., Maharjan, B., Maharjan, R., Malik, R. A., Nath, C. D., Nepal, B., Ngoma, J., Pant, R., Pathak, M. L., Paudel, H., Sharma, B., Hossain, M. S., Soronzonbold, B., Swe, T., Thapa, I. and Tiwari, A. 2016. Pinus roxburghiist and dynamics at a heavily impacted site in Nepal: Research through an educational fieldweek. Dendrochronologia. 41: 2-9.

Springate-Baginski, O., Dev, O. P., Yadav, N. P. and Soussan, J. 2003. Community forest management in the middle hills of Nepal: The changing context. Journal of Forest and 
Livelihood 3(1): 5-20

Stainton, A. 1997. Flowers of the Himalaya A Supplement. Oxford University Press, New Delhi, India.

Tang, Q. T., He, L., Su, W., Zhang, G., Wang, H., Peng, M., Wu, Z. and Wang, C. 2013. Regeneration, recovery and succession of a Pinus yunnanensis community five years after a mega-fire in central Yunnan, China. Forest Ecology and Management 294: 188196.

Tiwari D.N. 1994. A monograph on Chir pine (Pinus roxburghii Sarg). Dehradun: Indian Council of Forestry Research and Education.
Trincado,G., vander Schaaf,C.L. and Urkhart,H.E.2007.Regional mixed-effects height-diameter models for loblolly pine (Pinus taedaL.) plantations. European Journal of Forest Research 126: 253-262.

Wangda, P. and Ohsawa M. 2006. Structure and regeneration dynamics of dominant tree species along altitudinal gradient in a dry valley slopes of the Bhutan Himalaya. Forest Ecology and Management. 230: 136-150.

White, E. P., Morgan Ernest, S. K., Kerkhoff, A. J. and Enquist, B.J. 2007. Relationships between body size and abundance in ecology. Trends in Ecology and Evolution 22: 323-330. 